Journal of Animal and Veterinary Advances 18 (7): 239-245, 2019

ISSN: $1680-5593$

(C) Medwell Journals, 2020

\title{
Effect of Different Thawing Time and High Temperature on Frozen Thawed Bull Semen Traits
}

\author{
${ }^{1}$ Edis Yilmaz, ${ }^{2}$ Kemal Ak and ${ }^{2}$ Alper Baran \\ ${ }^{1}$ Bio Diagnostics Products Corporation-BIODPC, Buyukdere Caddesi, \\ Plaza 33 No:33 Kat: 3 D: 8-10 Mecidiyekoy, 34381, Sisli-Istanbul, Turkey \\ ${ }^{2}$ Department of Reproduction and Artificial Insemination, Faculty of Veterinary Medicine, \\ Istanbul University-Cerrahpasa, 34320 Avcilar, Istanbul, Turkey
}

\begin{abstract}
In this study was to investigate the effect of high temperature thawing and post-thaw cold shock application on sperm motility as well as acrosomal and total abnormalities of frozen bull semen. Four Holstein bulls were used to frozen semen in $0.25 \mathrm{~mL}$ straws. Semen of each bulls were thawed in $45 \mathrm{sec}$ at $37^{\circ} \mathrm{C}$ (Group $\mathrm{A}=$ Control group) in $15 \mathrm{sec}$ at $50^{\circ} \mathrm{C}$ (Group B) and $5 \mathrm{sec}$ at $70^{\circ} \mathrm{C}$ (Group C) and post-thawing cold shock $\left(300 \mathrm{sec}\right.$ at $\left.5^{\circ} \mathrm{C}\right)$ were applied to all groups. After spermatozoa motility and morphological examinations are performed sperm samples were incubated at $35^{\circ} \mathrm{C}$ for $120 \mathrm{~min}$ and spermatological traits were repeated. Semen samples from the control and treatment groups were placed in an incubator taking into consideration the medium conditions (Modified buffered Hepes medium) and the time needed for spermatozoa to reach the fertilization site. Motility and morphological defects rates were determined with phase contrast microscopy and motility rate and speed with sperm fertility analyser (SFA-500). The Hancock's solution was used for morphologic examination of spermatozoa (acrosome, other and total). In computer aided sperm fertility analyser, motility and movement were performed in according to the technique. In conclusion, it has been found that the conventional thawing method and rapid thawing technique are successful methods where the thawing method applied to Group B damaged spermatozoon viability. The rate of thawing in Group B did not protect the spermatozoa from dissolving or from the harmful effects of cold shock.
\end{abstract}

Key words: Bull, semen freezing, thawing time, temperature, sperm traits, successful

\section{INTRODUCTION}

In the artificial insemination procedure, the semen is exposed to different temperatures and osmotic pressures during the thawing of frozen sperm in the straws and after insemination. The exposure of spermatozoa to sudden temperature changes results in cold shock which negatively affects the mortality and morphology of the cells (Nur et al., 2006). It has been reported that different thawing methods could reduce negative effects of cold shocks and osmotic pressure changes in the cells (Correa et al., 1996; 1997; Borg et al., 1997). Spermatozoon damage which is caused by potential thermal changes of thawing, depends on the seasonal temperature and the practitioner's experience (duration of thawing, compatibility with the insemination procedure, etc.). Studies have reported that thawing at $21^{\circ} \mathrm{C}$ rather than $37^{\circ} \mathrm{C}$ develops osmotic pressure and temperature changes at a slower rate, resulting less damage (Borg et al., 1997; Correa et al., 1997).

The ability of spermatozoa to maintain their fertility after thawing depends on spermatozoon concentration, glycerol concentration, cooling rate, cryopreservation procedure and thawingprocedures (Robbins et al., 1976). In studies on thawing techniques high temperatures such as 60 and $80^{\circ} \mathrm{C}$ were experimented and successful motility rates were found (Ahmad, 1984; Narasimha Rao et al., 1986; Dhami et al., 1996). Some researchers have suggested thawing techniques to be at higher temperatures (Chandler et al., 1984; Nur et al., 2003; Rastegarnia et al., 2013).

Spermatozoon plasma membranes, outer acrosomal membranes and mitochondrial membranes are extremely sensitive to freezing and thawing processes. Unsaturated phospholipids in the membranes changes from the liquid phase to the gel phase during cooling (Watson, 1995). With this change of phase, membrane stabilization is deteriorated and cold shock damage occurs. In addition to this, the membranes rich in unsaturated phospholipids increase the susceptibility of spermatozoa to lipid peroxidation as a result of oxidative stress during cell freezing and thawing (Watson, 1995; Holt, 2000). These events which occur during freezing and thawing, cause damage to the membrane structure of the spermatozoon and reduces motility (Nur et al., 2006; Maxwell and Watson, 1996).

Corresponding Author: Alper Baran, Department of Reproduction and Artificial Insemination, Faculty of Veterinary Medicine, Istanbul University-Cerrahpasa, 34320 Avcilar, Istanbul, Turkey 
Tekeli and Çoyan stated that during the freezing and thawing of sperm, the critical temperature gradientis between -60 and $-10^{\circ} \mathrm{C}$. It is important to switch between these temperature intervals as fast as possible during the application of procedures and the ideal thawing in the mini straws happens in $7 \mathrm{sec}$ in a water bath of $75^{\circ} \mathrm{C}$. However, the researchers explain this temperature could be hard to achieve in practice and there is a risk of mini straw's inside temperature rising to $41^{\circ} \mathrm{C}$ causing the spermatozoa to denature. Therefore, the researchers suggested a temperature of $38 \pm 2^{\circ} \mathrm{C}$ for $25 \mathrm{sec}$ for thawing in mini straws of $0.25 \mathrm{~mL}$.

Foote (1989) stated that thawing must be achieved rapidly to minimize the damage caused by the change of ice crystals during thawing of sperm; motility, acrosomal integrity and potential fertility can be best maintained in this way. Gilbert and Almquist (1978) dissolved frozen bull spermatozoa in $0.3 \mathrm{~mL}$ straws at 35 for $10 \mathrm{sec}$, at $65^{\circ} \mathrm{C}$ for $7.5 \mathrm{sec}$ and at $95^{\circ} \mathrm{C}$ for $6 \mathrm{sec}$. They found that acrosomal integrity and spermatozoon motility is superior in thawing at $65^{\circ} \mathrm{C}$ for $7.5 \mathrm{sec}$ and at $95^{\circ} \mathrm{C}$ for $6 \mathrm{sec}$ than at $35^{\circ} \mathrm{C}$ for $10 \mathrm{sec}$.

Danasouri tried to detect the loss of acrosome enzymes acrosine and hyaluronidase as a result of various thawing procedures by thawing frozen bull spermatozoa in $0.5 \mathrm{~mL}$ straws at $5^{\circ} \mathrm{C}$ for $50 \mathrm{sec}$, at $37^{\circ} \mathrm{C}$ for $15 \mathrm{sec}$ and at $70^{\circ} \mathrm{C}$ for $7 \mathrm{sec}$. The highest acrosine activity in the spermatozoa and the lowest hyaluronidase activity in the environment were found at the group which were thawed in $7 \mathrm{~min}$ at $70^{\circ} \mathrm{C}$. The highest acrosomal damage occurred at $5^{\circ} \mathrm{C}$ in $50 \mathrm{sec}$. Tamyurek et al. thawed five Holstein bulls' straws at $37^{\circ} \mathrm{C}$ for $30 \mathrm{sec}$, at $50^{\circ} \mathrm{C}$ for $15 \mathrm{sec}$, at $75^{\circ} \mathrm{C}$ for $10 \mathrm{sec}$ and at $90^{\circ} \mathrm{C}$ for $5 \mathrm{sec}$. The researchers stated that there is no statistical difference in motility and acrosomal deterioration between these thawing techniques. The highest motility, $62.1 \%$ is reported for the $37^{\circ} \mathrm{C}$ for $30 \mathrm{sec}$ and the lowest acrosomal deterioration, $27.39 \%$ is reported at $90^{\circ} \mathrm{C}$ for $5 \mathrm{sec}$. DeJarnette et al. (2000) exposed $0.5 \mathrm{~mL}$ straws to 22,5 and $-18^{\circ} \mathrm{C}$ temperatures for 1, 2, 3, 4 or 5 min before or after thawing $\left(1 \mathrm{~min}\right.$ at $\left.37^{\circ} \mathrm{C}\right)$ and found that acrosomal integrity is more sensitive than motility. As time intervals increased and surrounding temperature dropped, the spermswere more damaged. Pace et al. (1981), using the rapid thawing technique, reported that freezing speed, thawing technique, and the concentration of glycerol in the diluents affect the viability after thawing. Investigators have reported that rapid thawing procedures extend the life span of cells after incubation at $37^{\circ} \mathrm{C}$ but there are contradictions between obtained results and field studies in terms of fertility.

Almquist (1976) reported that although, rapid high-temperature thawing methods were successful, it was difficult to control the heat, thus, these techniques were not suitable in the field. The researcher investigated the effects of thawing temperature and duration, on spermatozoon motility and morphology and found out that acrosomal deterioration is lower in fast thawing $(10 \mathrm{sec}$, $20 \mathrm{sec}$ and $80 \mathrm{sec}$ at $\left.35^{\circ} \mathrm{C}\right)$ than in slow thawing $(50 \mathrm{sec}$ at $\left.5^{\circ} \mathrm{C}\right)$. Andrey $(2015)$ reported that a high motility ratio was detected in the sperm frozen in $0.25 \mathrm{~mL}$ straws and thawed conventionally in a water bath of $65-70^{\circ} \mathrm{C}$ for 6-7 sec. It was reported that in rapid thawing, the damage caused by re-crystallization and hydration was less well characterized in the cytoplasm and cytoplasmic membranes.

Rapid thawing of the sperm protects the spermatozoon membrane and its cytoplasm from damage and reduces the negative effects of recrystallization process (Watson, 1995; Holt, 2000). Narasimha Rao et al. (1986) reported ice crystals must transition from solid state to liquid state without going into different forms as they pass through the critical temperature limit. In the field, it is advised that bull spermatozoa are thawed in a water bath at $35^{\circ} \mathrm{C}$ for at least $30 \mathrm{sec}$ (Nur et al., 2003; Dhami and Sahni, 1993; Hayashi and Isobe, 2005).

There are no adequate studies on whether there is a relationship between cold shock that can occur afterwards various thawing methods. In this study, conventional thawing technique $\left(45 \mathrm{sec}\right.$ at $\left.37^{\circ} \mathrm{C}\right)$ and higher temperature rapid thawing techniques were investigated and sperm were exposed to cold shocks. It was investigated if high temperature rapid thawing techniques could maintain the sperm cells against harmful effects of cold shock.

\section{MATERIALS AND METHODS}

In the study, frozen sperm from four Holstein bulls were used according to the straw method using the same diluent. The straws were stored in a $9 \mathrm{~L}$ site container (IMV, GT 9) until the day of the study. The frozen sperm on 0.25 straws belonging to four bulls were thawed in three different temperatures and durations in a water bath (double-boiler) sensitive at $\pm 1^{\circ} \mathrm{C}$. The method indicated a repetition of 50 times $(n=50)$ and two straws to beused for each group. In the study, 300 straws for a total of three groups were examined.

Group A (control): The frozen bull sperm in this group were thawed at $37^{\circ} \mathrm{C}$ for $45 \mathrm{sec}$.

Group B: Frozen sperm in group B was thawed at $50^{\circ} \mathrm{C}$ for $15 \mathrm{sec}$.

Group C: Frozen sperm forming the group $\mathrm{C}$ were thawed at $70^{\circ} \mathrm{C}$ for $5 \mathrm{sec}$.

Cold shock procedure: In order to induce a cold shock in the spermatozoa, the straws of group A, B and C were incubated for $300 \mathrm{sec}$ in the water bath at $5^{\circ} \mathrm{C}$ after thawing. 
120 min endurance tests at $35^{\circ} \mathrm{C}$ : After thawing and cold shocking, sperm in all groups were incubated for $120 \mathrm{~min}$ at $35^{\circ} \mathrm{C}$ and spermatological characteristics were examined.

Samples were stored in a polyurethane non-toxic plastic cuvette $(4 \mathrm{~mL})$ to enable the investigation of spermatological properties at the stages of thawing, cold shocking and endurance testing. Spermatological characteristics of spermatozoon motility, spermatozoon velocity and morphological abnormalities were examined in the above mentioned stages in all groups. Motility and morphological abnormalities were examined with phase-contrast microscope. Motility and spermatozoon speed were examined with sperm analysis device (Sperm Fertility Analyzers, SFA-500, Biola, Idalgen Medical, Turkey).

From all groups, $5 \mu \mathrm{L}$ semen samples were taken from the straws and transferred onto slides at $37^{\circ} \mathrm{C}$ and examined at 200 magnification on a phase-contrast microscope. Percentage (\%) values were calculated by taking the average of the motility ratios while taking into consideration the forward moving spermatozoa in three different areas. Semen samples $(5 \mu \mathrm{L})$ were transferred into tubes containing $1.0 \mathrm{~mL}$ Hancock's solution (Hancock, 1952). Samples $(5 \mu \mathrm{L})$ taken from this mixture was placed on a pre-ground slide and located on the slide before examining with immersed oil at 1000 magnification in a phase-contrast microscope. The acrosomal and other morphological abnormalities (head, mid-piece and tail abnormalities) were examined in 200 spermatozoa and the abnormality percentage (\%) were calculated.

Motility, speed, acrosome and other specifications as well as total morphological abnormalities were examined in semen samples after thawing and cold shocking at $5^{\circ} \mathrm{C}$ for $300 \mathrm{sec}$. The semen was diluted with "Modified Hepes Buffered Medium" as 1:9 (semen: medium) at $35^{\circ} \mathrm{C}$ after thawing and cold shocking, followed by incubation for
$120 \mathrm{~min}$ in an incubator of same temperature. At the end of this step, abnormalities regarding motility, speed, acrosome and other specifications as well as total morphological abnormalities were investigated.

Statistical analysis: Collected data were analysed using SPSS computer program (ANOVA). Duncan multiple rang test was performed to identify significant difference among the treatment means.

\section{RESULTS AND DISCUSSION}

The spermatological characteristics determined in different thawing techniques, regardless of the characteristics of the bulls are presented in Table 1. The highest motility values after thawing were obtained in Group A and Group C while the lowest motility value was obtained in Group B and the difference between the groups was statistically significant $(\mathrm{p}<0.001)$. Spermatozoon speed were similar in all groups $(\mathrm{p}>0.05)$. When morphological abnormalities were examined, the lowest values of acrosomal and total morphological abnormalities were found in Groups A and C. The highest values of acrosome and total morphological abnormalities were found in Group B $(\mathrm{p}<0.01)$. No statistically significant difference was detected between Group A, B and $\mathrm{C}$ in terms of other morphological abnormality values $(\mathrm{p}>0.05)$.

The spermatological characteristics of the bull sementhawed at different temperatures and durations, cold shocked at $5^{\circ} \mathrm{C}$ for 300 seconds are presented in Table 2 . The highest motility values were found in average in Group A and Group C while the lowest motility values were found in Group B for the thawed and cold shocked bull sperm; the difference between the values of the three groups was found statistically significant $(p<0.001)$. Also, there was no difference between the groups when the spermatozoon speed was compared $(\mathrm{p}>0.05)$. When

Table 1: Spermatological characteristics after thawing

\begin{tabular}{lllllll}
\hline & & & & \multicolumn{2}{l}{ Sperm morpholocical abnormality (\%) } \\
Groups (n $=150)$ & SFA motility (\%) & PCM motility $(\%)$ & Speed of sperm $(\mu \mathrm{s})$ & Intact acrosome & Other & Total \\
\hline $37^{\circ} \mathrm{C}-45 \mathrm{~s}($ Group A) & $54.62 \pm 3.02^{\mathrm{a}}$ & $54.76 \pm 2.51^{\mathrm{a}}$ & $72.14 \pm 2.18$ & $11.51 \pm 1.43^{\mathrm{b}}$ & $9.19 \pm 0.69$ & $20.70 \pm 1.58^{\mathrm{b}}$ \\
$50^{\circ} \mathrm{C}-15 \mathrm{~s}$ (Group B) & $39.23 \pm 3.33^{\mathrm{b}}$ & $41.55 \pm 2.84^{\mathrm{b}}$ & $68.74 \pm 1.89$ & $26.42 \pm 0.87^{\mathrm{a}}$ & $7.46 \pm 0.53$ & $33.88 \pm 0.99^{\mathrm{a}}$ \\
$70^{\circ} \mathrm{C}-5 \mathrm{~s}($ Group C) & $50.82 \pm 3.46^{\mathrm{a}}$ & $51.71 \pm 2.72^{\mathrm{a}}$ & $72.16 \pm 2.08$ & $15.52 \pm 0.95^{\mathrm{b}}$ & $8.02 \pm 0.53$ & $23.54 \pm 1.06 \mathrm{~b}$ \\
$\mathrm{p}$ values & $\mathrm{p}<0.001$ & $\mathrm{p}<0.01$ & $\mathrm{p}>0.05$ & $\mathrm{p}<0.01$ & $\mathrm{p}>0.05$ & $\mathrm{p}<0.01$ \\
\hline
\end{tabular}

SFA: Sperm Fertility Analyzer; PCM: Phase Contrast Microscopy; Other: Head-midpiece-tail sperm morphological abnormalities; values are mean $\pm \mathrm{SE}^{\text {abc: }}$. Within colum different small letters significant at $(\mathrm{p}<0.001, \mathrm{p}<0.01)$

Table 2: Effect of thawing temperature on spermatological characteristics after $300 \mathrm{sec}$ at $5^{\circ} \mathrm{C}$

\begin{tabular}{lllllll}
\hline & & & & \multicolumn{3}{c}{ Sperm morpholocical abnormality (\%) } \\
Groups (n=150) & SFA motility (\%) & PCM motility $(\%)$ & Speed of sperm $(\mu \mathrm{s})$ & Intact acrosome & Other & Total \\
\hline $37^{\circ} \mathrm{C}-45 \mathrm{~s}$ (Group A) & $47.47 \pm 3.40^{\mathrm{a}}$ & $46.57 \pm 2.88^{\mathrm{a}}$ & $70.89 \pm 2.47$ & $16.79 \pm 1.32^{\mathrm{b}}$ & $9.87 \pm 0.75$ & $26.66 \pm 1.60^{\mathrm{b}}$ \\
$50^{\circ} \mathrm{C}-15 \mathrm{~s}$ (Group B) & $33.94 \pm 3.45^{\mathrm{b}}$ & $35.68 \pm 3.03^{\mathrm{b}}$ & $70.52 \pm 1.78$ & $32.58 \pm 1.26^{\mathrm{a}}$ & $8.98 \pm 0.54$ & $41.56 \pm 1.32^{\mathrm{a}}$ \\
$70^{\circ} \mathrm{C}-5 \mathrm{~s}$ (Group C) & $43.56 \pm 3.36^{\mathrm{a}}$ & $43.96 \pm 2.63^{\mathrm{a}}$ & $70.40 \pm 2.17$ & $22.14 \pm 1.10^{\mathrm{b}}$ & $8.38 \pm 0.71$ & $30.52 \pm 1.21^{\mathrm{b}}$ \\
$\mathrm{p}-$ values & $\mathrm{p}<0.001$ & $\mathrm{p}<0.01$ & $\mathrm{p}>0.05$ & $\mathrm{p}<0.001$ & $\mathrm{p}>0.05$ & $\mathrm{p}<0.01$ \\
\hline SFA: Sprm
\end{tabular}

SFA: Sperm Fertility Analyzer; PCM: Phase Contrast Microscopy; Other: Head-midpiece-tail sperm morphological abnormalities; values are mean $\pm \mathrm{SE}^{\mathrm{abc}}$ : Within colum different small letters significant at $(\mathrm{p}<0.001, \mathrm{p}<0.01)$ 
J. Anim. Vet. Adv., 18 (7): 239-245, 2019

Table 3: Effect of thawing temperature on spermatological characteristics after incubationof 120 minutesat $35^{\circ} \mathrm{C}$

\begin{tabular}{|c|c|c|c|c|c|c|}
\hline \multirow[b]{2}{*}{ Groups $(\mathrm{n}=150)$} & \multirow[b]{2}{*}{ SFA motility (\%) } & \multirow[b]{2}{*}{ PCM motility (\%) } & \multirow[b]{2}{*}{ Speed of sperm $(\mu \mathrm{s})$} & \multicolumn{3}{|c|}{ Sperm morpholocical abnormality (\%) } \\
\hline & & & & Intact acrosome & Other & Total \\
\hline $37^{\circ} \mathrm{C}-45 \mathrm{~s}$ (Group A) & $24.69 \pm 2.31^{\mathrm{a}}$ & $24.35 \pm 2.43^{\mathrm{a}}$ & $69.01 \pm 3.57^{\mathrm{a}}$ & $41.57 \pm 2.57^{\mathrm{b}}$ & $8.42 \pm 0.61$ & $49.99 \pm 2.58^{b}$ \\
\hline $50^{\circ} \mathrm{C}-15 \mathrm{~s}$ (Group B) & $7.78 \pm 2.54^{\mathrm{b}}$ & $8.59 \pm 2.64^{\mathrm{b}}$ & $63.00 \pm 4.25^{\mathrm{b}}$ & $59.09 \pm 2.04^{\mathrm{a}}$ & $8.98 \pm 0.59$ & $68.08 \pm 2.00^{\mathrm{a}}$ \\
\hline $70^{\circ} \mathrm{C}-5 \mathrm{~s}$ (Group C) & $23.20 \pm 2.88^{\mathrm{a}}$ & $20.87 \pm 2.56^{\mathrm{a}}$ & $64.30 \pm 3.64^{\mathrm{b}}$ & $45.90 \pm 1.84^{\mathrm{b}}$ & $9.16 \pm 0.65$ & $55.06 \pm 2.02^{\mathrm{b}}$ \\
\hline $\mathrm{p}$ values & $\mathrm{p}<0.001$ & $\mathrm{p}<0.001$ & $\mathrm{p}<0.001$ & $\mathrm{p}<0.001$ & $\mathrm{p}>0.05$ & $\mathrm{p}<0.001$ \\
\hline
\end{tabular}

morphological abnormalities were examined, the lowest rates of acrosomal and total morphological abnormalities were obtained in Groups A and C. The highest values of acrosomal and total morphological abnormalities were in Group B and found statistically significant $(\mathrm{p}<0.01)$. There was no difference between groups $\mathrm{A}, \mathrm{B}$ and $\mathrm{C}$ among other morphological abnormalityrates.

The spermatological characteristics of the bull sementhawed at different temperatures and durations, cold shocked at $5^{\circ} \mathrm{C}$ for $300 \mathrm{sec}$ and incubated for $120 \mathrm{~min}$ at $35^{\circ} \mathrm{C}$ are presented in Table 3 . The highest motility values after incubation were found in average in Group A and Group $C$ while the lowest motility value was found in Group B; the difference between the values of the groups was found statistically significant $(p<0.001)$. When the speed of the spermatozoa was compared between the groups, the highest speed was detected in Group A while the lowest speed was detected in Group B and C $(p<0.001)$. When morphological abnormalities were evaluated, the lowest rates of acrosomal and total morphological abnormalities were found in Group A and C. The highest acrosomal and total morphological abnormalities were in Group B and the difference between the groups was found statistically significant $(p<0.001)$. There was no difference between groups A, B and $\mathrm{C}$ in other morphological abnormality values $(p>0.05)$. The highest value of acrosomal and total morphological abnormalities were in Group B and found statistically significant $(\mathrm{p}<0.01)$. There was no difference between groups $\mathrm{A}, \mathrm{B}$ and $\mathrm{C}$ among other morphological abnormality rates.

Successful artificial insemination requires a sufficient number of spermatozoa with high fertility. Bull sperms are affected by sudden temperature differences due to dilution, cooling, freezing, storing in containers, thawing. Following thawing spermatozoa get damaged. Thawing methods and the temperature during and after thawing are specifically important in the aforementioned steps. This is due to deep freeze storage, process control and the measures taken as precautions being applied more professionally in the lab and errors could be averted (Thibier and Wagner, 2002). However, in the field the environment and temperature can be unpredictable; experience of the practitioner, female cattle's temperament and cycle could harm the spermatozoa found in limited numbers in the straws and negatively effect pregnancy rates. The research carried out until now investigated thawing techniques of frozen sperm and the effect of cold shocks but not their correlation to each other in detail.

Different applications have been tested such as thawing in garment pocket with different incubation temperatures in the palm and in female genital tract Robbins et al., 1976). A number of studies have been conducted to determine the optimal thawing temperature and duration and to maintain the potential fertility of the sperm (Pace et al., 1981; Dhami and Sahni, 1993). Selçuk et al. found similar spermatozoon viability and morphological abnormalities in thawing procedures in the water bath $\left(37.5^{\circ} \mathrm{C}-25 \mathrm{sec}\right)$ and in the dry system $\left(37.5^{\circ} \mathrm{C}-25 \mathrm{sec}\right)$ and suggested that the dry system could be recommended for practical reasons. It has been reported that the lack of a consensus among researchers on the optimal thawing technique leads to faulty methods being utilized (Barth and Bowmen, 1988). In this research, the results from two different motility examination procedures, phase contrast microscope and sperm fertility analyzer are reported to be in harmony with each other there is no difference in the findings. Both methods were found eligible to be used for obtaining data.

Thawing speed which can be adjusted with the water bath temperature and duration of the procedure, effects the acrosomal integrity and motility rates and determines the success of artificial insemination practices. Curry and Watson (1994) reported that the main problem of thawing sperm in low temperatures is the damage caused by the osmotic changes. These are caused by the water entering the cell and the damage caused was more detrimental than the dehydration-induced changes during freezing. Danasouri (1988) found that the highest acrosomal abnormality occurred in thawing at $5^{\circ} \mathrm{C}$ from the methods of thawing at $5^{\circ} \mathrm{C}$ in $50 \mathrm{sec}, 37^{\circ} \mathrm{C}$ in $15 \mathrm{sec}$ and $70^{\circ} \mathrm{C}$ in $7 \mathrm{sec}$. Spermatozoon damage which is caused by the thermal changes after thawing is related to the seasonal temperature and experience of the practitioner (duration of melting, compatibility with the seeding procedure, etc.). Studies have reported that osmotic pressure and temperature changes in spermatozoa develop at a slower rate at thawing at $21^{\circ} \mathrm{C}$ than thawing at $37^{\circ} \mathrm{C}$, resulting in less damage (Borg et al., 1997; Correa et al., 1997). It is known that techniques which practice longer 
thawing times at lower temperatures, reduce potential fertility of the sperm by damaging acrosomal integrity and motility (DeJarnette and Marshall, 2005). For this reason, our study did not investigate slow thawing techniques at low temperatures.

It is suggested that the sperm should be thawed for 30-40 sec at body temperature during field studies (Correa et al., 1997; Nur et al., 2003; Rugg et al., 1977). Unless a specific recommendation is given, thawing for 30-40 sec in a $33-35^{\circ} \mathrm{C}$ water bath is recommended, regardless of the diluent type and freezing procedure (DeJarnette et al., 2000; DeJarnette and Marshall, 2005). In field applications, it is advised to dissolve bull sperm in a water bath at $35^{\circ} \mathrm{C}$ for at least $30 \mathrm{sec}$ (Dhami et al., 1996; Hayashi and Isobe, 2005). In this study, conventional thawing technique $\left(37^{\circ} \mathrm{C}-45 \mathrm{sec}\right)$ was used as a control group and compared with shorter thawing techniques at higher temperatures. For this purpose, sperm in $0.25 \mathrm{~mL}$ straws were thawed at $50^{\circ} \mathrm{C}$ for $15 \mathrm{sec}$ (Group B) or at $70^{\circ} \mathrm{C}$ for $5 \mathrm{sec}$ (Group C). The purpose here is to change the temperature faster in the straw.

At some stages in the study, we detected spermatological differences between the bulls. Differences between individual bulls in their fresh and frozen sperms have been reported by many investigators and it can be stated that post-thaw spermatological characteristics are within acceptable limits in all bulls (Medeiros et al., 2002).

In our study, the lowest motility values after melting were determined as $39.23 \pm 3.33$ and $41.55 \pm 2.84$, respectively $(\mathrm{p}<0.001)$ at $50^{\circ} \mathrm{C}$ for $15 \mathrm{sec}$ with Sperm Fertility Analyser (SFA) and Phase Contrast Microscope (PCM). The high motility values were found out, again with SFA and PCM to be54.62 \pm 3.02 and 54.76 \pm 2.5 in the control group $\left(37^{\circ} \mathrm{C}-45 \mathrm{sec}\right)$ and $50.82 \pm 3.46$ and $51.71 \pm 2.72$ in group $\mathrm{C}\left(70^{\circ} \mathrm{C}-5 \mathrm{sec}\right)$. The same is true for acrosomal deterioration and total morphological abnormalities. A (Control), B and $\mathrm{C}$ groups had $11.51 \pm 1.43, \quad 26.42 \pm 0.87, \quad 15.52 \pm 0.95$ acrosomal deterioration, respectively and $20.70 \pm 1.58,33.88 \pm 0.99$, $23.54 \pm 1.06$ total morphological abnormalities were detected (Table 1).

It is known that the osmotic shock that occurs at the time of thawing damages the vitality and morphology of the spermatozoon (Correa et al., 1996; Correa et al., 1997). After sudden temperature change, osmotic pressure and mechanical shocks, osmotic and mechanical stress, membrane protein denaturation, structural deformations, DNA damage and cellular lysis occur in the sperm (Maxwell and Watson, 1996; Peris et al., 2007).

Rapid thawing techniques have been reported to be effective in reducing the harmful effects of freezing and thawing on the sperm (Mazur, 1984). It is stated that rapid thawing techniques positively affect spermatozoon motility and acrosomal integrity (Robbins et al., 1976;
Dhami et al., 1996; Nur et al., 2003). Forde and Gravir detected a better sperm motility at high temperatures such as 60 and $80^{\circ} \mathrm{C}$. Rugg et al. (1977) obtained very high pregnancy rates of 56.0 and $55.3 \%$ in thawing techniques of $12 \mathrm{sec}$ at $35^{\circ} \mathrm{C}$ and $7 \mathrm{sec}$ at $75^{\circ} \mathrm{C}$, respectively. Foote (1998) stated that thawing process must be carried out fast to minimize the damage caused by the changes in ice crystals during the unfreezing of the sperm, so that, the motility, acrosomal integrity and potential fertility are maintained in the best possible way. Gilbert and Almquist (1978) compared melting techniques at $35^{\circ} \mathrm{C}$ for $10 \mathrm{sec}$, at $65^{\circ} \mathrm{C}$ for $7.5 \mathrm{sec}$ and at $95^{\circ} \mathrm{C}$ for $6 \mathrm{sec}$ and found higher rates of motility at higher temperatures.

In our study, similar spermatological properties were determined in thawing techniques at $70^{\circ} \mathrm{C}$ for $5 \mathrm{sec}$ compared to the control group. The fast thawing technique did not have a positive or negative effect at high temperatures. Although, the obtained values support most researchers recommending thawing techniques at $37^{\circ} \mathrm{C}$ and higher, they do not comply with the studies which find rapid thawing techniques useful at high temperatures such as $70^{\circ} \mathrm{C}$. Several factors such as diluent type, glycerol concentration and freezing methods affect the success of the thawing of the frozen sperm (Bailey et al., 2000; 2008; Chakrabarty et al., 2007). The differences in the laboratory conditions, the chemicals used, the difference in instruments and the materials used in different countries are also important (Thibier and Wagner, 2002). Thus, the methods used to freeze and unfreeze the semen in the laboratories and the features they possess in different countries should be investigated separately. Muino et al. (2008) thawed frozen bull spermatozoa in $0.25 \mathrm{~mL}$ straws for $40 \mathrm{sec}$ at $37^{\circ} \mathrm{C}, 15 \mathrm{sec}$ at $50^{\circ} \mathrm{C}$ and $5 \mathrm{sec}$ at $70^{\circ} \mathrm{C}$ and did not report a negative effect on spermatozoon motility, plasma and acrosomal membrane integrity for these different thawing techniques. Pace et al. (1981) who used rapid thawing techniques, demonstrated that rapid thawing methods prolonged the life span of cells after incubation at $37^{\circ} \mathrm{C}$, however, they further reported that there were contradictions between the measured spermatological quality and post-insemination fertility levels. Our study shows thawing techniques of $37^{\circ} \mathrm{C}$ for $45 \mathrm{sec}$ and $70^{\circ} \mathrm{C}$ for $5 \mathrm{sec}$ to be both feasible according to the findings obtained before cold shocking and incubation.

In group $\mathrm{B}$, thawing at $50^{\circ} \mathrm{C}$ for $15 \mathrm{sec}$ damaged both morphological integrity and motility $(\mathrm{p}<0.01)$. The low quality data obtained in this group was unexpected. Muino et al. (2008) investigated the same thawing technique and reported similar results in all groups and even reported that thawing at $50^{\circ} \mathrm{C}$ may be less harmful than thawing at $70^{\circ} \mathrm{C}$ or at $35^{\circ} \mathrm{C}$. These results do not match our results; in fact, they are contradictory to each other. 
Tekeli and Çoyan suggested that critical temperature range for thawing of sperm is between -60 and $-10^{\circ} \mathrm{C}$ and the temperature should be changed as quickly as possible during freezing and thawing. Lyashenko (2015) reported that in a $38^{\circ} \mathrm{C}$ water bath, the temperature of the straw reached $0^{\circ} \mathrm{C}$ in the first $5 \mathrm{sec}$ and $30^{\circ} \mathrm{C}$ in the 15 th sec. Kaya et al. reported when the sperm were being thawed, the straws were aimed to reach the internal temperature of $20^{\circ} \mathrm{C}$ within a short period of time. Tekeli and Çoyan stated that permanent damage to spermatozoa occurs if the temperature inside the straw is raised above $41^{\circ} \mathrm{C}$. Low values in group B can be attributed to characteristics of bulls, diluents, laboratory conditions and freezing techniques as mentioned above. It can be concluded that the rate of thawing in this technique (Group B) is not at a level that can protect spermatozoa in phase changes and at critical temperatures.

It could be stated about this study that the spermatological properties were generally impaired after the application of cold shock and this state continued after the incubation. It has been reported that cold shocks induced from the sudden cooling of the sperm under $17^{\circ} \mathrm{C}$ and the resulting decrease in oxygen binding capacity in cells decreases motility and fructose ratios and halts ATP synthesis (Quinn and White, 1996). It is known that cold shocks after thawing increases morphological abnormalities and affect motility in the negative direction (Nur et al., 2003; DeJarnette et al., 2000). Especially during cold winter days, pregnancy rates decrease in artificial insemination applications below $17^{\circ} \mathrm{C}$ (Nicholas and Maizel, 1989).

Motility, acrosomal and total morphology values were found in $\mathrm{A}$ and $\mathrm{C}$ groups and lowest spermatological characteristics were found in Group B after cold shock (Table 2) and incubation at $37^{\circ} \mathrm{C}$. The conventional thawing technique in the control group $\left(45 \mathrm{sec}\right.$ at $\left.37^{\circ} \mathrm{C}\right)$ and the high temperature thawing technique $(5 \mathrm{sec}$ at $70^{\circ} \mathrm{C}$ ) were found to be successful and the difference between them was insignificant. The thawing method at $50^{\circ} \mathrm{C}$ for $15 \mathrm{sec}$ yield the worst results before and after cold shock treatment and after incubation. The rate of thawing in Group B did not protect the spermatozoa from dissolving or from the harmful effects of cold shock.

\section{CONCLUSION}

It has been found that the conventional thawing method $\left(45 \mathrm{sec}\right.$ at $\left.37^{\circ} \mathrm{C}\right)$ and rapid thawing technique (5 sec at $70^{\circ} \mathrm{C}$ ) are successful methods where the thawing method applied to Group B $\left(15 \mathrm{sec}\right.$ at $\left.50^{\circ} \mathrm{C}\right)$ damaged spermatozoon viability. The different thawing methods investigated in this study do not differ in the case of negative effects of cold shocking.

\section{ACKNOWLEDGEMENTS}

The present work was supported by the Research Fund of Istanbul University. Project No. 5723/25.02.2010.

\section{REFERENCES}

Ahmad, K., 1984. Effect of thaw rates on survival of buffalo spermatozoa frozen in straws. J. Dairy Sci., 67: 1535-1538.

Almquist, J.O., 1976. Effect of cold shock after thawing on acrosomal maintenance and motility of bovine spermatozoa frozen in plastic straws. J. Dairy Sci., 59: $1825-1829$.

Bailey, J.L., C. Lessard, J. Jacques, C. Breque, I. Dobrinski, W. Zeng and H.L. Galantino-Homer, 2008. Cryopreservation of boar semen and its future importance to the industry. Theriogenology, 70: 1251-1259.

Bailey, J.L., J.F. Bilaodean and N. Cormier, 2000. Semen cryopreservation in domestic animals: A damaging capacitating phenomenon. J. Androl., 20: 1-7.

Barth, A.D. and P.A. Bowman, 1988. Determination of the best practical method of thawing bovine semen. Can. Vet. J., 29: 366-369.

Borg, K., B. Colenbrander, A. Fazeli, J. Parlevliet and L. Malmgren, 1997. Influence of thawing method on motility, plasma membrane integrity and morphology of frozen-thawed stallion spermatozoa. Theriogenology, 48: 531-536.

Chakrabarty, J., D. Banerjee, D. Pal, J. De and A. Ghosh et al., 2007. Shedding off specific lipid constituents from sperm cell membrane during cryopreservation. Cryobiology, 54: 27-35.

Chandler, J.E., R.W. Adkinson and R.L. Nebel, 1984. Thawing optimums for bovine spermatozoa processed by three methods and packaged in continental and French straws. J. Dairy Sci., 67: 398-404.

Correa, J.R., G. Heersche and P.M. Zavos, 1997. Sperm membrane functional integrity and response of frozen-thawed bovine spermatozoa during the hypoosmotic swelling test incubation at varying temperatures. Theriogenology, 47: 715-721.

Correa, J.R., M.C. Rodriguez, D.J. Patterson and P.M. Zavos, 1996. Thawing and processing of cryopreserved bovine spermatozoa at various temperatures and their effects on sperm viability, osmotic shock and sperm membrane functional integrity. Theriogenology, 46: 413-420.

Correa, J.R., M.M. Pace and P.M. Zavos, 1997. Relationships among frozen-thawed sperm characteristics assessed via the routine semen analysis, sperm functional tests and fertility of bulls in an artificial insemination program. Theriogenolgy, 48: 721-731.

Curry, M.R. and P.F. Watson, 1994. Osmotic effects on ram and human sperm membranes in relation to thawing injury. Cryobiology, 31: 39-46.

Danasouri, I.E., 1988. Effect of thawing temperature on the loss of acrosin and hyaluronidase enzymes from bovine spermatozoa. Theriogenology, 29: 1343-1346. 
De Jarnette, J.M. and C.E. Marshall, 2005. Straw-thawing method interacts with sire and extender to influence sperm motility and conception rates of dairy cows. J. Dairy Sci., 88: 3868-3875.

DeJarnette, J.M., D.A. Barnes and C.E. Marshall, 2000. Effects of pre-and post-thaw thermal insults on viability characteristics of cryopreserved bovine semen. Theriogenology, 53: 1225-1238.

Dhami, A.J. and K.L. Sahni, 1993. Evaluation of different cooling rates, equilibration periods and diluents for effects on deep-freezing, enzyme leakage and fertility of taurine bull spermatozoa. Theriogenelogy, 40: $1269-1280$.

Dhami, A.J., K.L. Sahni, G. Mohan and V.R. Jani, 1996. Effects of different variables on the freezability, post-thaw longevity and fertility of buffalo spermatozoa in the tropics. Theriogenology, 46: 109-120.

Foote, R.H., 1989. Preservation and fertility prediction of spermatozoa. Proceedings of the 11th International Congress on Animal Reproduction and Artificial Insemination, Belfield Campus, June 26-30, 1988, University College Dublin, Dublin, Ireland, pp: 127-134.

Foote, R.H., 1998. Artificial Insemination to Cloning: Tracing 50 Years of Research. Cornell University, Ithaca, New York, USA., ISBN: 9780960531486, Pages: 231.

Gilbert, G.R. and J.O. Almquist, 1978. Effects of processing procedures on post-thaw acrosomal retention and motility of bovine spermatozoa packaged in. 3-ml straws at room temperature. J. Anim. Sci., 46: 225-231.

Hancock, J.L., 1952. The morphology of bull spermatozoa. J. Exp. Biol., 29: 445-453.

Hayashi, Y. And N. Isobe, 2005. Characteristics of cryopreserved spermatozoa from a Holstein-Friesian bull thawed at different temperature. J. Int. Dev. Coop., 12: 107-110.

Holt, W.V., 2000. Basic aspects of frozen storage of semen. Anim. Reprod. Sci., 62: 3-22.

Lyashenko, A., 2015. Effect of different thawing procedures on the quality and fertility of the bull spermatozoa. Asian Pac. J. Reprod., 4: 17-21.

Maxwell, W.M.C. and P.F. Watson, 1996. Recent progress in the preservation of ram semen. Anim. Reprod. Sci., 42: 55-65.

Mazur, P., 1984. Freezing of living cells: Mechanisms and implications. Am. J. Physiol. Cell Physiol., 247: C125-C142.

Medeiros, C.M.O., F. Forell, A.T.D. Oliveira and J.L. Rodrigues, 2002. Current status of sperm cryopreservation: Why isn't it better? Theriogenology, 57: 327-344.
Muino, R., M. Rivera, T. Rigau, J.E. Rodriguez-Gil and A.I. Pena, 2008. Effect of different thawing rates on post-thaw sperm viability, kinematic parameters and motile sperm subpopulations structure of bull semen. Anim. Reprod. Sci., 109: 50-64.

Narasimha Rao, A.V., G.B. Haranath, G. Soma Sekharam and J. Ramamohana Rao, 1986. Effect of thaw rates on motility, survival and acrosomal integrity of buffalo spermatozoa frozen in medium French straws. Anim. Reprod. Sci., 12: 123-129.

Nicholas, L. and S. Maizel, 1989. Methods for evaluating the acrosomal status of mammalian sperm. Biol. Reprod., 41: 635-641.

Nur, Z., I. Dogan, M.K. Soylu and K. Ak, 2003. Effect of different thawing procedures on the quality of bull semen. Rev. Med. Vef., 154: 487-490.

Nur, Z., I.K. Ileri and K. Ak, 2006. Effects of different temperature treatments applied to deep stored bull semen on post-thaw cold shocked spermatozoa. Bull. Vet. Inst. Pulawy, 50: 79-83.

Pace, M.M., J.J. Sullivan, F.I. Elliott, E.F. Graham and G.H. Coulter, 1981. Effects of thawing temperature, number of spermatozoa and spermatozoal quality on fertility of bovine spermatozoa packaged in.5- $\mathrm{ml}$ French straws. J. Anim. Sci., 53: 693-701.

Peris, S.I., J.F. Bilodeau, M. Dufour and J. Bailey, 2007. Impact of cryopreservation and reactive oxygen species on DNA integrity, lipid peroxidation and functional parameters in ram sperm. Mol. Reprod. Dev., 74: 878-892.

Quinn, P.J. and I.G. White, 1966. The effect of cold shock and deep-freezing on the concentration of major cations in spermatozoa. Reproduction, 12: $263-270$.

Rastegarnia, A., A. Shahverdi, T.R. Topraggaleh, B. Ebrahimi and V. Shafipour, 2013. Effect of different thawing rates on post-thaw viability, kinematic parameters and chromatin structure of buffalo (Bubalus bubalis) Spermatozoa. Cell J., 14: 306-313.

Robbins, R.K., R.H. Saacke and P.T. Chandler, 1976. Influence of freeze rate, thaw rate and glycerol level on acrosomal retention and survival of bovine spermatozoa frozen in french straws. J. Anim. Sci., 42: 145-154.

Rugg, C.D., W.E. Berndtson, R.G. Mortimer and B.W. Pickett, 1977. Effect of thawing procedures on fertility of bovine spermatozoa frozen in.25-ml straws. J. Anim. Sci., 44: 266-270.

Thibier, M. and H.G. Wagner, 2002. World statistics for artificial insemination in cattle. Livestock Prod. Sci., 74: 203-212.

Watson, P.F., 1995. Recent developments and concepts in the cryopreservation of spermatozoa and the assessment of their post-thawing function. Reprod. Fertil. Dev., 7: 871-891. 